\title{
The Oxidation of Glycosides. XVII. Preparation of Some Methyl-hexodialdopyranoside-(1,5)-s
}

\author{
BIRGITTA PETTERSSON and OLOF THEANDER*
}

Chemistry Department, Swedish Forest Products Research Laboratory, Box 5604, S-114 86 Stockholm, Sweden

The 6-aldehydo derivatives of methyl 3-O. methyl- $\beta$-D-glucopyranoside and of the anomeric methyl glycopyranosides from L-glucose, $\mathrm{I}_{\text {--mannose, D-galactose, and D-gulose have }}$ been prepared. During the oxidation of methyl 3-O-methyl- $\beta$-D-glucopyranoside small amounts of two keto-compounds were obtained: methyl 3-O-methyl- $\beta$-D-arabino-hexopyranosidulose and another one, which most likely is a diketo derivative of the parent glucoside.

The previously unreported methyl $\alpha$ - and $\beta$-D-glycero-D-talo-heptopyranosides were also prepared.

It was observed that 6-aldehydo derivatives of methyl $\beta$-D-glucopyranoside and its 4-O. methyl derivative were hydrolysed much faster than the unoxidised glucosides. ${ }^{1}$ In order to study this effect in some detail, a number of 6-aldehydo-hexosides have been prepared, and their acid hydrolysis will be investigated. In the present paper we report the synthesis of methyl 3-O-methyl- $\beta$-D-glucohexodialdopyranoside-(1,5) (I), the 6-aldehydo derivatives of the anomeric methyl glycopyranosides of L-glucose (II, III), L-mannose $(\mathrm{IV}, \mathrm{V})$, D-galactose (VI, VII), and D-gulose (VIII, IX).

Methyl 3-O-methyl- $\beta$-D-gluco-hexodialdopyranoside-(1,5) (I) was prepared by a route similar to that followed for the corresponding 4- $O$-methyl derivative, ${ }^{2}$ that is, by oxidation of methyl 3-O-methyl- $\beta$-D-glucopyranoside with chromium trioxide in acetone and subsequent fractionation of the products on carbon and

* Present address: Department of Chemistry, Div. II, Agricultural College of Sweden, S-750 07 Uppsala, Sweden.

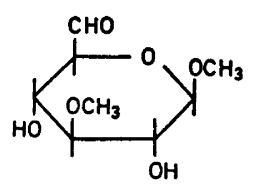

I

cellulose columns. Compound I was obtained as an amorphous $\left([\alpha]_{D}{ }^{20}-13^{\circ}\right)$ material and showed the chromatographic and electrophoretic properties of an aldehydo-glycoside. ${ }^{3}$ The structure was demonstrated through the following reactions: Borohydride reduction gave only one product, methyl 3-O-methyl- $\beta$ D-glucopyranoside which, when hydrolysed, released only one sugar, 3-O-methyl-D-glucose. After acid hydrolysis of $I$ to the free dialdose, partial reduction and demethylation with

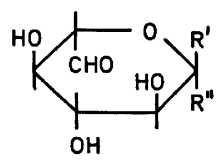

II $\quad R^{\prime}=\mathrm{OCH}_{3} ; R^{\prime \prime}=\mathrm{H}$

III $R^{\prime}=\mathrm{H}_{i} R^{\prime \prime}=\mathrm{OCH}_{3}$

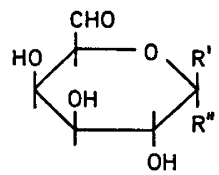

II $\mathrm{R}^{\prime}=\mathrm{H}_{;} \mathrm{R}^{\prime \prime}=\mathrm{OCH}_{3}$

VII $\mathrm{R}^{\prime}=\mathrm{OCH}_{3} ; \mathrm{R}^{\prime \prime}=\mathrm{H}$

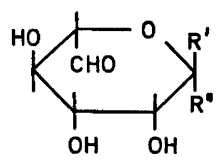

IV $\mathrm{R}^{\prime}=\mathrm{OCH}_{3} ; \quad \mathrm{R}^{\prime \prime}=\mathrm{H}$

I $R^{\prime}=\mathrm{H}_{i} \mathbf{R}^{\prime \prime}=\mathrm{OCH}_{3}$

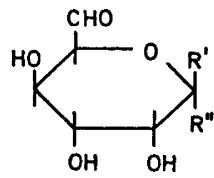

VIII $R^{\prime}=H \quad R^{\prime \prime}=\mathrm{OCH}_{3}$

IX $\mathrm{R}=\mathrm{OCH}_{3} \quad \mathrm{R}^{\prime}=\mathrm{H}$ 


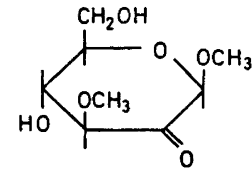

$\mathrm{X}$

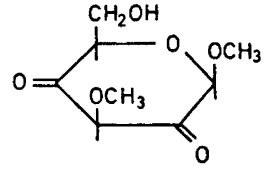

XI boron trichloride, 4 glucose and gulose were the only monosaccharides detectable by paper chromatography and electrophoresis. Besides, supporting the structures of $I$, this result also indicated that no isomerisation of $I$ or its hydrolysis product had occurred during the acid treatment.

Preparation of compound I was the primary object of this experiment, but two ketocompounds, formed in small amounts were also characterised. One of these compounds was amorphous $\left([\alpha]_{D}{ }^{20}-32^{\circ}\right)$ and according to its chromatographic properties and migration in hydrogen sulphite electrophoresis ${ }^{3,5}\left(\mathbf{M}_{\text {vanillin }}=\right.$ 0.39 , cf. 1.19 for compound I), appeared to be a mono-keto derivative. After borohydride reduction and demethylation this compound gave glucose and mannose as the only detect- able monosaccharides, indicating that the compound is methyl 3-O-methyl- $\beta$-D-arabinohexopyranosidulose (X).

The other compound was obtained crystalline (m.p. $141-142^{\circ} ;[\alpha]_{\mathrm{D}}{ }^{20}-45.2^{\circ}$ ) and its chromatographic properties, migration in hydrogen sulphite electrophoresis $\left(M_{\text {vanillin }}=1.37\right)^{3,5}$ and elemental analysis indicated that it was a diketo compound, which make structure XI most likely. Borohydride reduction and demethylation yielded glucose, galactose, and small amounts of mannose as the main products in agreement with the proposed structure, XI.

D-Galactose oxidase has been widely used to oxidise the hydroxyl group at C-6 in D-galactopyranose residues to an aldehyde group., ${ }^{6}, 7$ The reaction is used when analysing such residues or when making tritium labelled compounds via reduction. ${ }^{8}$ A discussion of previous work and substrate specificity of this oxidase has been published. ${ }^{2}$ In the present work this method was used for the preparation of methyl $\beta$-D-galactohexodialdopyranoside-(1,5) from the corresponding galactoside. The reaction was not at all complete which is in accordance with the

Table 1. Preparation of methyl heptopyranosides.

\begin{tabular}{|c|c|c|c|c|c|}
\hline \multirow{2}{*}{ Substance } & \multirow{2}{*}{$\begin{array}{l}\text { Yield } \\
\%\end{array}$} & \multicolumn{2}{|l|}{ Melting point } & \multicolumn{2}{|c|}{$[\alpha]_{D}^{20}\left(\mathrm{H}_{2} \mathrm{O}\right)$} \\
\hline & & obs. & lit. & obs. & lit. \\
\hline $\begin{array}{l}\text { Methyl } \alpha \text {-D-glycero-D-gulo-hepto- } \\
\text { pyranoside }\end{array}$ & 22 & - & $104-107^{015}$ & $+111.5^{\circ}$ & $+112^{\circ 15}$ \\
\hline $\begin{array}{l}\text { Methyl } \beta \text {-D-glycero-D-gulo-hepto- } \\
\text { pyranoside }\end{array}$ & 41 & $171-172^{\circ}$ & $168-169^{\circ 15}$ & $-70^{\circ}$ & $-75^{\circ 15}$ \\
\hline $\begin{array}{l}\text { Methyl } \alpha \text {-D-glycero-D-ido-hepto- } \\
\text { pyranoside }\end{array}$ & 13 & 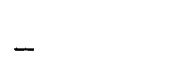 & 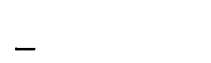 & $+80^{\circ}$ & - \\
\hline $\begin{array}{l}\text { Methyl } \beta \text {-D-glycero-D-ido-hepto- } \\
\text { pyranoside }\end{array}$ & & & & & \\
\hline $\begin{array}{l}\text { pyranoside } \\
\text { Methyl } \alpha \text {-D-glycero-D-talo-hepto- }\end{array}$ & 7 & - & - & $-38^{\circ}$ & - \\
\hline $\begin{array}{l}\text { Methyl } \alpha \text {-D-glycero-D-talo-hepto- } \\
\text { pyranoside } \\
\text { Methyl } \beta \text {-D-glycero-D-talo-hepto- }\end{array}$ & 13 & $196-197^{\circ}$ & - & $+83.6^{\circ}$ & - \\
\hline $\begin{array}{l}\text { pyranoside } \\
\text { Methyl } \alpha \text {-D-glycero-D-galacto-hepto- }\end{array}$ & 7 & $136.5-138^{\circ}$ & - & $-48.0^{\circ}$ & - \\
\hline $\begin{array}{l}\text { pyranoside } \\
\text { Methyl } \beta \text {-D-glycero-D-galacto-hepto- }\end{array}$ & 29 & $141-143^{\circ}$ & $141^{116}$ & $+179^{\circ}$ & $+178^{\circ 16}$ \\
\hline $\begin{array}{l}\text { pyranoside } \\
\text { Methyl } \alpha \text {-D-glycero-L-gluco-hepto- }\end{array}$ & 2 & $166-169^{\circ}$ & $168^{\circ 16}$ & $+16^{\circ}$ & $-5.1^{016}$ \\
\hline $\begin{array}{l}\text { pyranoside } \\
\text { Methyl } \beta \text {-D-glycero-L-gluco-hepto- }\end{array}$ & 13 & $167,5-169^{\circ}$ & $154-155^{\circ 16}$ & $-142^{\circ}$ & $-108^{\circ 15}$ \\
\hline $\begin{array}{l}\text { pyranoside } \\
\text { Methyl } \alpha \text {-D-glycero-L-manno-hepto- }\end{array}$ & 4 & $185-187^{\circ}$ & $182-183^{\circ 15,17}$ & $+36.8^{\circ}$ & $+36^{\circ 15,17}$ \\
\hline $\begin{array}{l}\text { pyranoside } \\
\text { Methyl } \beta \text {-D-glycero-L_manno-hepto- }\end{array}$ & 55 & $132-133^{\circ}$ & $132^{\circ 15,18}$ & $-70^{\circ}$ & $-70.2^{\circ 15,18}$ \\
\hline $\begin{array}{l}\text { pyranoside } \\
\text { pyra-Dincero-manno-hepto- }\end{array}$ & 5 & - & - & $+74^{\circ}$ & $+74^{\text {o16 }}$ \\
\hline
\end{tabular}


Table 2. Preparation of methyl hexodialdopyranoside-(1,5)-s.

Methyl 3-O-methyl $\beta$-D-gluco-hexodialdopyranoside-(1,5) (I)

Methyl $\alpha$-L-gluco-hexodialdopyranoside-(1,5) (II)

Methyl $\beta$-I,-gluco-hexodialdopyranoside- $(1,5)$ (III)

Methyl $\alpha-L_{-}-$manno-hexodialdopyranoside-(1,5) (IV)

Methyl $\beta$-L-manno-hexodialdopyranoside-(1,5) (V)

Methyl $\alpha$-D-galacto-hexodialdopyranoside-( $(1,5)$ (VI)

Methyl $\beta$-D-galacto-hexodialdopyranoside-(1,5) (VII)

Methyl $\alpha$-D-gulo-hexodialdopyranoside-(1,5) (VIII)

Methyl $\beta$-D-gulo-hexodialdopyranoside $(-1,5)$ (IX)

\begin{tabular}{|c|c|c|}
\hline & 10 & $-13^{\circ}$ \\
\hline & 44 & $-120^{\circ}$ \\
\hline & 70 & $+40^{\circ}$ \\
\hline & 60 & $-60^{\circ}$ \\
\hline & 28 & $+69^{\circ}$ \\
\hline & $\begin{array}{c}34 \\
8^{b}\end{array}$ & \\
\hline & $\begin{array}{l}31 \\
47\end{array}$ & $+116^{\circ}$ \\
\hline
\end{tabular}

$a$ Prepared from the methyl heptoside with periodate oxidation. ${ }^{b}$ Prepared from the methyl galactoside with enzymatic oxidation.

results obtained from oxidation of o-nitrophenyl- $\beta$-D-galactopyranoside. ${ }^{8}$

The aldehydo compound obtained from enzyme action was shown to be identical with a sample prepared by the route discussed below. Further verification of the structure was obtained by hydrolysis to galacto-hexodialdose and by conversion to galacturonic acid by bromine oxidation and hydrolysis.

Antia and Perry ${ }^{10}$ prepared methyl $\beta$-D. gulopyranoside by oxidation of methyl $\beta$-Dglycero-D-gulo-heptopyranoside with $1 \mathrm{~mol}$ of periodate to the 6-aldehydo-glycoside, followed by borohydride reduction. We have used this synthetic route, but stopping at the 6 -aldehydo stage, in the preparation of a series of methyl hexodialdopyranoside-(1,5)-s. The heptoses prepared from $\mathrm{D}$-glucose by the cyanohydrin synthesis and from D-mannose and D-galactose by the nitromethane synthesis, were glycosidated with methanol-hydrogen chloride. The products after glycosidation were fractionated on a basic ion-exchange resin column. ${ }^{11}$ Yields and properties of the pure anomeric methyl heptosides obtained are summarised in Table 1. Methyl $\alpha$-and methyl $\beta$-D-glycero-D-talo-hepto-

Table 3. Electrophoretic mobilities of the aldehydo-glycosides and corresponding dialdoses.

Substance

Methyl $\beta$-D-gluco-hexodialdopyranoside- $(1,5)$

Methyl 4- $O$-methyl $\beta$-D-gluco-hexodialdopyranoside-(1,5)

Methyl 3-O-methyl $\beta$-D-gluco-hexodialdopyranoside-(1,5)

Methyl $\alpha$-L - gluco-hexodialdopyranoside- $(1,5)$

Methyl $\beta$-L-gluco-hexodialdopyranoside-(1,5)

Methyl $\alpha-L-$ manno-hexodialdopyranoside- $(1,5)$

Methyl $\beta$-L-manno-hexodialdopyranoside-(1,5)

Methyl $\alpha$-D-galacto-hexodialdopyranoside- $(1,5)$

Methyl $\beta$-D-galacto-hexodialdopyranoside-(1,5)

Methyl $\alpha$-D-gulo-hexodialdopyranoside- $(1,5)$

Methyl $\beta$-D-gulo-hexodialdopyranoside- $(1,5)$

D-Gluco-hexodialdose

4-O-Methyl D-gluco-hexodialdose

3-O-Methyl-D-gluco-hexodialdose

L-gluco-Hexodialdose

$L$-manno-Hexodialdose

D-galacto-Hexodialdose

D-gulo-Hexodialdose

$\begin{array}{ll}\text { Hydrogen } & \text { Borate } \\ \text { sulphite } & \\ \text { pH 4,7 } & \text { pH } 10 \\ \mathrm{M}_{\text {vanillin }} & \mathrm{M}_{\text {glucose }}\end{array}$

$\begin{array}{ll}1.25 & 0.62 \\ 1.22 & 0 \\ 1.19 & 0.57 \\ 1.07 & 0.47 \\ 1.25 & 0.60 \\ 1.17 & 0.66 \\ 1.29 & 0.62 \\ 1.29 & 0.30 \\ 1.45 & 0.43 \\ 1.25 & 0.52 \\ 1.33 & 0.73 \\ 1.36 & 1.15 \\ 1.29 & 0.78 \\ 1.26 & 0.98 \\ 1.36 & 1.15 \\ 1.57 & 0.79 \\ 1.43 & 0.93 \\ 1.42 & 1.09\end{array}$

Acta Chem. Scand. B 28 (1974) No. 1 
pyranosides have, to our knowledge, not been previously reported.

The heptosides (1 mol) were oxidised at low temperature with periodate $(1.05-1.15 \mathrm{~mol})$. The products were fractionated by cellulose column chromatography and amorphous, but, according to paper chromatography and electrophoresis, pure fractions of the 6-aldehydoglycopyranosides II - IX were obtained. Yields, based on the heptosides used as starting materials, and optical properties of the pure top-fractions are given in Table 2. The corresponding derivatives of $\mathrm{D}$-idose and $\mathrm{D}$-talose were obtained in small yields only and were impure.

Characteristic for aldehydo-glycopyranosides as well as for dialdoses and osuloses is the appearance on the paper chromatograms of elongated spots, which are often multiple with tailing between, which indicates equilibria between various isomeric forms. ${ }^{3}$ This, of course, complicates the chromatographic purification of the aldehydo-glycosides. On paper electrophoresis, either in hydrogen sulphite ${ }^{5}$ or borate buffer, the aldehydo-glycosides show characteristic mobilities and give distinct spots (Table 3). Studies on the acid hydrolysis of the aldehydo-glycosides will be reported separately.

\section{EXPERIMENTAL}

Concentrations were carried out under reduced pressure below $40^{\circ}$. The following solvent systems were used for paper chromatography:

A. Butan-1-ol-ethanol-water (10:3:5).

B. Ethyl acetate-acetic acid-water (3:1:1).

C. Ethyl acetate-pyridine-water $(8: 2: 1)$.

In paper electrophoresis the following buffers were used:

D. 0.1 M Sodium hydrogen sulphite, ${ }^{5} \mathrm{pH} 4,7$ at $40^{\circ}$.

E. 0.1 M Borate, pH 10 .

F. 0.4 M Boric acid, $1.0 \mathrm{M}$ glycerol, $\mathrm{pH} 6.8$ at $40^{\circ} .12$

Whatman No. 1 papers were used for the chromatographic separations. Visualization of the spots was through the following conventional carbohydrate spray reagents: $p$. anisidine hydrochloride, silver nitrate-sodium hydroxide and resorcinol-hydrochloric acid.

Preparation and characterisation of methyl 3-O-methyl- $\beta$-D-gluco-hexodialdopyranoside- $(1,5)$ (I). Methyl 3-O-methyl- $\beta$-D-glucopyranoside was prepared as previously reported..$^{13,14}$ The glucoside was oxidised in a way similar to that described for the corresponding 4-O-methyl ether. ${ }^{2}$

Chromium trioxide $(8.3 \mathrm{~g})$ in small portions was added with agitation to cold, freshly distilled acetone $(835 \mathrm{ml})$. A solution of the glucoside $(12.5 \mathrm{~g})$ in cold acetone $(250 \mathrm{ml})$ was poured in a slow stream to the agitated chromium trioxide solution. The temperature was kept below $+15^{\circ}$. The reaction mixture was then kept at room temperature for half an hour and after that refluxed for $1 \mathrm{~h}$. After cooling, the precipitate was filtered off and heated under reflux with acetone $(4 \times 175 \mathrm{ml})$ with intermediate filtrations. The combined filtrates were concentrated to a small volume and diluted with water to a final volume of $200 \mathrm{ml}$. The aqueous solution was extracted with chloroform $(4 \times 100 \mathrm{ml})$ and then treated with cation exchanger (Dowex 50, $\mathrm{H}^{+}$) and anion exchanger (Dowex 3, free base). After concentration the oxidation product was separated on a carbon.Celite column $(6.5 \times 70 \mathrm{~cm})$ and eluted with aqueous ethanol $0-25 \%(201)$ and, subsequently, with $75 \%$ ethanol (4 1). The fraction $(0.65 \mathrm{~g})$ which contained the aldehydocompound, also contained some starting material and probably some keto-compounds and was further fractionated on a silicic acid column $(3.5 \times 50 \mathrm{~cm})$ with chloroform-ethanol $(3: 1)$ as eluent.

A chromatographically and electrophoretically pure top-fraction of methyl 3-O-methyl$\beta$-D-gluco-hexodialdopyranoside-(1,5) I $(0.16 \mathrm{~g})$ was obtained (but the total amount of the aldehyde was considerably higher). The compound I was identified as follows. I $(0.037 \mathrm{~g})$ was reduced with excess potassium borohydride and after reaction the solution was treated with cation exchanger (Dowex 50, $\mathrm{H}^{+}$) and evaporated. Remaining boric acid was removed by evaporation with methanol. The reduction product, according to paper chromatography (solvent $\mathrm{A}$ and $\mathrm{B}$ ) and thin layer chromatography in chloroform-ethanol (3:1), was identical with authentic methyl 3-O-methyl- $\beta$-D-glucopyranoside. No further products were detected. The reduction product $(0.022 \mathrm{~g})$ was hydrolysed and the crystalline product obtained (m.p. $164.5-166.5^{\circ}$ ) was identified as 3-O-methylD-glucose by IR, mixed m.p., and its chromatographic properties compared to authentic material. No other sugars were detected in the mother liquor.

Part of compound I was treated with $0.5 \mathrm{M}$ sulphuric acid at $80^{\circ}$ for $4 \mathrm{~h}$. After neutralisation with barium carbonate, the product was reduced with an amount of potassium borohydride sufficient to convert one aldehyde group only. After demethylation ${ }^{4}$ with boron trichloride in methylene chloride at $-80^{\circ}$ the mixture of monosaccharides was investigated by paper chromatography (solvent $\mathrm{A}, \mathrm{B}$, and C) and electrophoresis (buffer E and F). These separations revealed the presence of the ex- 
pected sugars glucose and gulose, but the absence of the other hexoses.

During the separation of the oxidation products, two other compounds, giving yellow colour with the anisidine spray, were collected (a: $0.010 \mathrm{~g}$ and $\mathrm{b}: 0.018 \mathrm{~g}$ ).

Substance a was crystalline and after recrystallisation from ethanol exhibited a m.p. of $141-142^{\circ},[\alpha]_{\mathrm{D}}{ }^{20}-45.2^{\circ}$ (c 0.6 water), and no mutarotation. Elemental analysis gave: C 47,1; H 6.44; O 47.0. Diketo compound $\mathrm{C}_{8} \mathrm{H}_{12} \mathrm{O}_{6}$ requires: $\mathrm{C} 47.1 ; \mathrm{H}$ 5.92; $\mathrm{O} 47.0$; and monoketo compound $\mathrm{C}_{8} \mathrm{H}_{14} \mathrm{O}_{6}$ requires: $\mathrm{C} 46.6$; $\mathrm{H}$ 6.85; O 46.7. $\mathrm{M}_{\text {vanillin }}=1.37$ in buffer $\mathrm{D}$ and the elemental analysis indicated that the compound was a diketo compound. It was reduced with excess potassium borohydride and the reduction product was demethylated with boron trichloride in methylene chloride at $-80^{\circ}$. Paper chromatography (solvents A, $B$, and $C$ ) and paper electrophoresis (buffer $\mathrm{E}$ and $\mathrm{F}$ ) revealed the presence of glucose, galactose, and small amounts of mannose as the only sugars. This indicates that the positions of the keto groups are at C-2 and C-4 in methyl 3-O-methyl glucoside.

Mass spectrometry gave $\mathrm{M}^{+}$204, which correspond to structure XI. No more material was available for further elucidation of the structure.

Compound b was a chromatographically pure, amorphous compound, $[\alpha]_{\mathrm{D}}{ }^{20}-32^{\circ}$ (c 0.3 water). After reduction and demethylation as above, glucose and mannose were the only sugars detected by paper chromatography and electrophoresis. This indicates that the compound has one keto group at C-2 and thus is methyl 3-O-methyl- $\beta$-D-arabino-hexopyranosidulose $(X)$. The mobility in hydrogen sulphite electrophoresis $\left(M_{v}=0.39\right)$ is characteristic of a monoketo-glycoside.

Preparation and characterisation of methyl $\beta$-D-galacto-hexodialdopyranoside- $(1,5)$ (VI). In small scale experiments the extent of oxidation of methyl $\beta$-D-galactopyranoside with D-galactose oxidase was estimated by paper chromatography. When amounts of enzyme reasonable for preparative scale work were used, the oxidation was far from complete.

In a typical larger scale experiment methyl $\beta$-D-galactopyranoside $(3.30 \mathrm{~g})$ in $0.01 \mathrm{M}$, $\mathrm{pH}$ 7.0, phosphate buffer $(330 \mathrm{ml})$ containing catalase $(0.16 \mathrm{~g})$ and galactose oxidase $(0.066 \mathrm{~g})$; was shaken for $1.5 \mathrm{~h}$ at $37^{\circ}$. Both enzymes were obtained from Worthington Biochemical Company. Ethanol (80 ml), active carbon (10 g) and some Celite was added and the stirred mixture filtered and washed with $25 \%$ ethanol. After standing in the cold one day some inorganic salts could be filtered off.

The filtrate was evaporated to a small volume, passed through ion exchange columns of Dowex $50\left(\mathrm{H}^{+}\right)$and Dowex 3 (free base) and evaporated to dryness. Some methyl $\beta$-Dgalactopyranoside $(0.90 \mathrm{~g})$ was removed after crystallisation and the mother liquor was fractionated on a cellulose column (Whatman CF 11 powder, $4.5 \times 85 \mathrm{~cm}$ ) using solvent $A$. A top-fraction of compound VI $(0.27 \mathrm{~g})$ was collected and was pure according to paper chromatography and electrophoresis.

Part of compound VI was hydrolysed with $0.5 \mathrm{M}$ sulphuric acid at $100^{\circ}$ for $4 \mathrm{~h}$ and the product obtained shown to be identical (by paper chromatography and electrophoresis) with a sample of galacto-hexodialdose prepared by a Rosenmund reduction of tetra- $O$-acetylgalactaroyl dichloride. ${ }^{19}$ Another part of VI was transformed to a product shown to be identical with galacturonic acid by bromine oxidation $^{20}$ and acid hydrolysis with $0.5 \mathrm{M}$ sulphuric acid at $100^{\circ}$ for $4 \mathrm{~h}$.

Preparation and characterisation of the methyl hexodialdopyranoside-(1,5)-s $(I I-I X)$. The general route for the preparation of compounds II-IX was preparation of heptoses, glycosidation of the latter with methanol/hydrogen chloride and separation of the resulting anomeric methyl heptopyranosides. Controlled periodate oxidation of the pure heptosides and chromatographic purification of the corresponding methyl hexodialdopyranoside- $(1,5)$-s was then performed. Yields and physical properties of the methyl heptopyranosides and of the methyl hexodialdopyranoside $(1,5)$-s are given in Tables 1 and 2, respectively. Paper electrophoretic properties of the latter and the corresponding hexodialdoses are given in Table 3 . The yields in Table 1 are based on the heptoses and in Table 2 on the methyl heptopyranosides.

D-glycero-D-gulo-Heptopyranose and D-glyceroD-ido-heptopyranose were prepared by cyannhydrin synthesis from D-glucose, ${ }^{21}$ but the reductions of the intermediate heptono-1,4lactones were made with sodium borohydride ${ }^{22}$ instead of sodium amalgam. ${ }^{21} \mathrm{D}$-glycero-Dgalacto-Heptopyranose and D-glycero-D-taloheptopyranose were prepared as previously reported by nitromethane condensation and the Nef reaction starting from D-mannose..$^{23-25}$ D-glycero-L-manno-Heptopyranose and D-glyceroL-gluco-heptopyranose were similarly prepared but starting from D-galactose ${ }^{26}$ instead of the D-mannose.

The same conditions for the glycosidation were used for all heptoses and were essentially as previously described. ${ }^{15}$ To a solution of the heptose in methanol, was added a methanol/hydrogen chloride mixture to give a final concentration of $10 \%$ sugar and $1.5 \%$ hydrogen chloride. After refluxing the solution for $6 \mathrm{~h}$, most of the solvent was removed under reduced pressure at $30^{\circ}$. Water was then added and the solution neutralised with an anion exchange resin (Dowex 3, free base). The resulting mixture of methyl glycosides was fraction. ated on an anion exchange column (Dowex 1-X8, $\mathrm{OH}^{-}, 200-400$ mesh). ${ }^{11}$ Pyranosides were eluted faster than furanosides (the latter were not collected) and $\alpha$-pyranosides 
Table 4. Characterisation of the aldehydo-glycosides by (A) reduction and (B) hydrolysis and subsequent reduction.

Compound

Reaction products

A

$\mathrm{B}^{a}$

Methyl $\alpha$-L-gluco-hexodialdopyranoside-(1,5) (II)

Methyl $\alpha$-L-glucopyranoside

Glucitol

(identified by paper chromatog-

raphy and electrophoresis)

Methyl $\beta$-L-gluco-hexodialdopyranoside-(1,5) (III)

Methyl $\beta$-L-glucopyranoside

(identified as above)

Methyl $\alpha$-L-manno-hexodialdopyranoside-(1,5) (IV)

Methyl $\alpha$-L-mannopyranoside

Glucitol

(identified as above)

Methyl $\beta$-I-manno-hexodialdopyranoside-(1,5) (V)

Methyl $\boldsymbol{\beta}$-L-mannopyranoside

Mannitol

(identified as above)

Methyl $\alpha$-D-galacto-hexodialdopyranoside-(1,5) (VI)

Methyl $\alpha$-D-galactopyranoside

Mannitol

(identified as above)

Methyl $\beta$-D-galacto-hexodialdopyranoside-(1,5) (VII)

Methyl $\alpha$-D-gulo-hexodialdopyranoside-(1,5) (VIII)

Methyl $\beta$-D-galactopyranoside

(identified as above)

$[\alpha]_{D^{20}}+110^{\circ}\left(\mathrm{H}_{2} \mathrm{O}\right)$ found

$[\alpha]_{\mathrm{D}}{ }^{20}+109.4^{\circ}\left(\mathrm{H}_{2} \mathrm{O}\right)$ lit.

Galacticol

Me $\alpha$-D-gulopyranoside

$[\alpha]_{D}{ }^{20}-80.5^{\circ}\left(\mathrm{H}_{2} \mathrm{O}\right)$ found

Galactitol

Methyl $\beta$-D-gulo-hexodialdopyranoside-(1,5) (IX)

$[\alpha]_{\mathrm{D}}{ }^{20}-8^{\circ}\left(\mathrm{H}_{2} \mathrm{O}\right)$ lit. Me $\beta$-D-gulopyranoside

$a$ The retention times of the hexaacetates on GLC were: mannitol 0.78 , galactitol 0.89 , glucitol 1.00 and, as comparison, iditol 1.22 .

well separated from $\beta$-pyranosides. The separations were followed polarimetrically and by paper-chromatography and pure fractions of anomeric methyl heptopyranosides were obtained. The physical data of the crystalline compounds were in good agreement with previously reported values (Table 1). To our knowledge the methyl $\alpha$ - and $\beta$-D-glycero-Dtalo-heptopyranosides have not been previously reported. Elemental analysis: required for the methyl heptosides C 42.9; H 7.20; O 50.0. Obtained for methyl $\alpha-\mathrm{D}$-glycero-D-talo-heptoside, C 43.2; H 7.10; O 49.6. Obtained for methyl $\beta$-D-glycero-D-talo-heptoside, C 43.1; H 7.30; O 49.4 .

The periodate oxidation of the various methyl heptopyranosides was made essentially as previously described for the oxidation of methyl $\beta$-D-glycero-D-gulo-heptopyranoside,${ }^{10}$ but with somewhat more than the theoretical amount of periodate. Based upon smallscale experiments the following excess was used in the preparations (otherwise made under similar conditions): $5 \%$ and $15 \%$ excess of sodium metaperiodate for the methyl $\alpha$-D-glycero-Dgulo-heptoside and its $\boldsymbol{\beta}$-anomer, respectively, and otherwise $10 \%$ excess. The preparation procedure (10\% excess of oxidant) was as follows:

To a solution of the methyl heptoside $(1.00 \mathrm{~g}$ in $50 \mathrm{ml}$ water) at $0^{\circ}$ was added with stirring $0.09 \mathrm{M}$ sodium metaperiodate $(55 \mathrm{ml})$ while maintaining the temperature below $+3^{\circ}$. After one hour stirring at room temperature the solution was kept at $+4^{\circ}$ for $20 \mathrm{~h}$. Barium carbonate equivalent to the original periodate was then added and the mixture again stirred. After filtering, ion exchange (Dowex 50, $\mathrm{H}^{+}$ and Dowex 3, free base) and evaporation to a syrup, the product, obtained by extraction with warm $50 \%$ ethanol, was (after evaporation) fractionated on a cellulose column $(90 \times 4 \mathrm{~cm})$ using butan-1-ol saturated with water as eluent. Top-fractions (both fast- and slowmoving with similar equilibrium patterns) of pure methyl hexodialdopyranoside- $(1,5)$-s were collected (Table 2).

The aldehydo-glycosides were amorphous but behaved as pure components on paper chromatography and paper electrophoresis ${ }^{3}$ (Table 3).

Each of them yielded essentially one component, the dialdose, on acid hydrolysis. Borohydride reduction of the aldehydo-glycosides and the dialdoses yielded the expected glycosides and alditols, respectively (Table 4).

\section{REFERENCES}

1. Theander, O. Acta Chem. Scand. 18 (1964) 1297.

2. Assarsson, A. and Theander, O. Acta Chem. Scand. 18 (1964) 727.

3. Theander, O. Advan. Carbohyd. Chem. 17 (1962) 223.

4. Bonner, T. G., Bourne, E. J. and McNally, S. J. Chem. Soc. (1960) 2929.

5. Theander, O. Acta Chem. Scand. 11 (1957) 1557.

Acta Chem. Scand. B 28 (1974) No. 1 
6. Avigad, G., Asensio, C., Amaral, D. and Horecker, B. L. Biochem. Biophys. Res. Commun. 4 (1961) 474.

7. Avigad, G., Amaral, D., Asensio, C. and Horecker, B. L. J. Biol. Chem. 237 (1962) 2736.

8. Avigad, G. Carbohyd. Res. 3 (1967) 430.

9. Schlegel, R. A., Gerbeck, C. M. and Montgomery, R. Carbohyd. Res. 7 (1968) 193.

10. Antia, N. J. and Perry, M. B. Can. J. Chem. 38 (1960) 1917.

11. Austin, P. W., Hardy, F. E., Buchanan, J. G. and Baddiley, J. J. Chem. Soc. (1963) 5350.

12. Pettersson, B. and Theander, O. Acta Chem. Scand. 27 (1973) 1900.

13. Glen, W. L., Myers, G. S. and Grant, G. A. $J$. Chem. Soc. (1951) 2568.

14. Helferich, B. and Lang, O. J. Prakt. Chem. 132 (1932) 321.

15. Isbell, H. S. J. Res. Nat. Bur. Stand. 24 (1940) $125,146$.

16. Montgomery, E. M. and Hudson, C. S. J. Amer. Chem. Soc. 64 (1942) 247.

17. Hann, R. M. and Hudson, C. S. J. Amer. Chem. Soc. 59 (1937) 548.

18. Hann, R. M., Merril, A. T. and Hudson, C. S. J. Amer. Chem. Soc. 56 (1934) 1644; 57 (1935) 2100.

19. Lewis, B. A., Smith, F. and Stephen, A. M. Methods Carbohyd. Chem. 2 (1963) 45.

20. Isbell, H. S. Methods Carbohyd. Chem. 2 (1963) 13.

21. Richtmyer, N. K. Methods Carbohyd. Chem. 1 (1962) 160 .

22. Wolfrom, M. L. and Thomson, A. Methods Carbohyd. Chem. 2 (1963) 66.

23. Sowden, J. C. and Schaffer, R. J.Amer. Chem. Soc. 73 (1951) 4662.

24. Pierce, G. J. Biol. Chem. 23 (1915) 327.

25. Sowden, J. C. and Thompson, R. R. J. Amer. Chem. Soc. 80 (1958) 2236.

26. Sowden, J. C. and Strobach, D. R. J. Amer. Chem. Soc. 82 (1960) 954.

Received August 18, 1973. 